In 1940 and 1941 a hydrographical expedition discovered evidence of early habitation on the most northerly island of the Ostrova Faddeya and on the shore of the mainland opposite, in Zaliv Simsa. This locality is on the eastern side of Poluostrov Taymyr, about 75-100 miles south-east of Mys Chelyuskina. The objects found included copper vessels, knives, frying pans, tin plates, silver coins, ear-rings, a flintlock weapon, and crosses of the sort that are hung round the neck. There were also found remains of a boat, sledges and huts, with human skeletons in the latter, and, of particular interest, a compass, a sun watch, and a document appearing to be letters patent. The coins, of which altogether more than $\mathbf{3 4 0 0}$ were found, belong to various reigns, from that of Vasili III, who ruled in Moscow from 1505 to 1533, to that of Tsar Mikhail Fedorovich, who ruled from 1613 to 1645 . From this, and the evidence provided by other objects, it would seem that this locality was reached by Russians from towns on the White Sea and Barents Sea, such as Mezen, Kholmogora (Hakluyt's Colmogro) and Pustozersk, in the first quarter of the seventeenth century. In fact it is likely that the journey or journeys were made before 1620 , since in that year a decree was issued forbidding absolutely all trading by the sea route from the west to the mouth of the $\mathrm{Ob}^{\prime}$. This decree had the intended effect of stopping the development of shipping routes in the Kara Sea. It seems probable that the expedition was both trading and hunting, and that it suffered shipwreck while on the way to the mouth of the Khatanga. It is surmised, from the range of objects evidently intended for use in trading with natives, that those making the expedition had a very clear idea of the conditions and needs of the Siberian market. It is possible, therefore, that this particular party which was shipwrecked off eastern Taymyr was not the first to make the journey.

\title{
"ZEMLYA SANNIKOVA"
}

[Based on Izvestiya Vsesoyuznogo Geograficheskogo Obshchestva (News of the All-Union Geographical Society), Tom 78, No. 3, 1946, pp. 357-58; Morya sovetskoy arktiki (Seas of the Soviet Arctic) by V. Yu. Vize, Leningrad, 1936.]

It has recently been announced that Zemlya Sannikova, or Sannikov Land, has been conclusively proved not to exist. A geographical puzzle that had exercised explorers of that part of the Russian Arctic for over 130 years has thus at last been solved.

Between 1805 and 1811 Yakov Sannikov, a trader, travelled extensively over the Ostrova Novosibirskie (New Siberian Islands), a group of islands lying in the Arctic Ocean off the north Siberian coast between the mouths of the Lena and the Indigirka. From the northern coast of Novaya Sibir', the most easterly island of the group, he saw land due north out to sea. This was evidently what is now called Ostrov Bennett, an island reached and named in 1881 by de Long. From the northern tip of Ostrov Faddeyevski, in the centre of the group, he claimed to see land in a northerly direction, about 30 miles away. The absence of any land in this area was proved shortly afterwards by a subsequent expedition. From the northern shore of Ostrov Kotel'ny, at the western 
end of the group, he claimed to see land to the north-west. It is this last which came to be called Zemlya Sannikova.

In 1823 the Governor-General of Siberia gave instructions to Lieutenant P.F. Anzhu, who since 1820 had been exploring the Ostrova Novosibirskie and the mainland coast opposite them, to look for Zemlya Sannikova. Although he reached the northern end of Ostrov Kotel'ny, he saw no sign of land farther north. The next explorer to visit the islands was Baron E. von Toll', who was there in 1886. From a point on the north shore of Ostrov Kotel'ny he clearly saw, on a fine day, "the sharp outline of four mountains, joined at their eastern end to some low lying ground". This, however, was north-north-east from the point of observation, while Sannikov had seen land to the north-west, but Toll' was convinced both were part of the same archipelago. Toll' was in the area again in 1893 and one of his party, an Even (then called Lamut) tribesman named Dzhergeli, had spent seven summers hunting on the Ostrova Novosibirskie, and he claimed to have seen Zemlya Sannikova several times. Toll' and he rivalled each other in their eagerness to reach it. Toll' estimated its distance from the mainland at 100-130 miles and even claimed to have seen enough of it to say that it was of basaltic structure. On his return to St Petersburg he put the whole question before the Academy of Sciences, with the result that an expedition was sent out in 1900 in the Zarya, under the leadership of Toll', with the object of resolving the problem. The Zarya reached the area in 1901, but on the two occasions on which the ship passed close to the spot it was too foggy to say whether there was any land in the vicinity or not. 'The same trouble had prevented Nansen in the Fram from seeing anything in 1893.

Since 1920 , after which year shipping began to appear comparatively often in the area, the number of "white spots" in which Zemlya Sannikova might still be found, was reduced; but not quickly, since the normal sea route passed south and not north of the Ostrova Novosibirskie. In 1937 three Soviet icebreakers were caught in drifting ice west of the Ostrova Novosibirskie, and drifted northwards and then eastwards. The Zemlya Sannikova area was crossed twice, and in the spring of 1938 it was crossed three more times by aircraft taking people from these icebreakers to the mainland.

There still remained, however, two possible areas which had not yet been traversed by any ship or aircraft. At the request of Academician V. A. Obruchev, the Northern Sea Route Administration agreed to plan some of its ice reconnaissance flights in 1944 in such a way as to cover these areas. Two flights were planned by D. B. Karelin: one was to be due north from the Lena delta, the other due north from the mouth of the Indigirka, and each was to search an area roughly between latitude $78^{\circ} \mathrm{N}$. and $80^{\circ} \mathrm{N}$. These two flights were duly completed in July and August 1944. Visibility in each case was good over the area to be searched, and the observers saw only occasional open water pools separated by broad expanses of drifting ice, on the surface of which there were not even signs of hummocking which might have been caused by land in the vicinity. 